\title{
COMPARATIVE ANALYSIS OF THE ACCOMMODATION ONLINE OFFER FOR BĂILE FELIX (ROMANIA) AND HAJDÚSZOBOSZLÓ (HUNGARY)
}

\section{Olimpia Ban Laurențiu Droj}

https://doi.org/10.20867/tosee.05.50

\begin{abstract}
The purpose of this paper is to compare the accommodation offer of the two resorts (Băile Felix and Hajdúszoboszló), as it is presented on the booking reservation platform, both in quantitative and qualitative terms. The specific objectives of the study are: identifying the objective differences resulting from the quantitative and qualitative analysis of the accommodation offer of the two resorts, as evidenced by the information provided by Booking.com; identifying the quantitative and structural differences of accommodation reviewers; the comparative analysis of ratings obtained on the seven quality assessment characteristics and types of accommodation structure; determining the weight of negative comments in total comments and the issues mentioned in negative reviews by their frequency. Statistical analysis was performed for comparative quantitative and qualitative analysis, on the Booking.com basis data. A sample consisting of 20$30 \%$ of the listed units was formed, respecting the weight by type of structure. For comment analysis, content analysis was used, which is a technique often used in text analysis by code schemes. More than 16,000 ratings and over 9,000 total comments and over 700 negative comments from 512 (120-selected in sample) accommodation structures in the two resorts were analyzed. Were discovered in the course of conducting this research: because of significant differences observed in the structure of the accommodation units types and their star rating, the comparison in terms of classification is not relevant in this case; taking into account the perceived quality reflected in the Booking.com score, there are no significant differences between the two resorts, but quite a symmetrical arrangement; the nationality structure of the visitors who made a rating on Booking.com for that two resorts is quite different but not like travel mode; the analysis of total comments shows a slightly higher weight of negative comments for Băile Felix and the comparative analysis on quality characteristics revealed minor differences for that two resorts, below $0.3 \%$, but the deeper analysis of the negative comments posted revealed important different quality problems for two resorts. An interesting observation resulted from survey is that for the same average of assessments, the conclusions may be very different on the same resort or even the same accommodation structure. This analysis is restricted by the fact that not all the accommodation offer of the two resorts is listed on Booking.com and that different offers are shown differently both in quantity and in structural terms, so it may not have been taken into account either at least all existing units on Booking.com on the date of your search.The empirical contribution is that this work makes an analysis that has not been done in the past for these resorts. This research is valuable because it compares the information on the two resorts on the very popular booking platform, Booking.com. In addition, there are two resorts in direct competition and positioned close to each other. The practical implications of this study are valuable, by the results obtained, for the tourism operators in the two resorts. There are known sources of consumer dissatisfaction and these are analyzed comparatively on the two competing resorts. The
\end{abstract}


ToSEE - Tourism in Southern and Eastern Europe, Vol. 5, pp. 73-88, 2019

O. Ban, L. Droj: COMPARATIVE ANALYSIS OF THE ACCOMMODATION ONLINE OFFER FOR ...

implications of the study are of a social nature, considering that the high complaints of tourists are also related to discrimination issues, felt in the accommodation structures. The scientific contribution of the study is that it highlights the need to know the importance given by reviewers to the quality characteristics (in accordance with Importance-Performance Analysis), in order to properly assess the satisfaction of the consumers of tourist services.

Keywords online evaluation, accomodation, resorts, Romania, Hungary

\section{INTRODUCTION TO THE ONLINE ASSESSMENT OF ACCOMMODATION SERVICES}

Increasing customer retention has advantages, an important one is in increasing the profit (Reichheld and Schefter, 2000 in Berezina et al., 2015,4) and then contributes to positive word marketing through WOM and thanks to the Internet, eWOM, attracting new customers.

The online environment has opened a new path in researching consumer perceptions of the quality of accommodation services and their satisfaction. Internet development and access to it has led to a huge amount of consumer-generated content with valuable information for providers, customers, competitors, researchers, and so on. eWOM sources had gets very important in the consumer decision making process and (some) the reviewers became travel opinion leaders (Litvin, Goldsmith and Pan, 2008, 19). Prior to the development of the Internet, it was difficult for hoteliers to collect consumer impressions, as Berezina et al. $(2015,2)$ points out: "(..) the problem presents itself in guests' unwillingness to share their experiences and provide feedback to hotels".

Reseller platforms allow and encourage post-consumer expression and interaction of current clients with site visitors, reflected by the amazing abundance of comments and ratings posted on communication platforms (Berezina et al., 2015, 2). "More importantly, e-WOM about hotels may express customer satisfaction and dissatisfaction more clearly and precisely, including comparative information on service performance of the competitors." (Li et al., 2013, 790).

On the other hand, the comments posted by consumers are increasingly read and taken into account in the decision making process. "Recent market research revealed that $49 \%$ of consumers will not book a hotel without reading any consumer reviews" (Olery, 2012 in $\mathrm{Wu}$ et al., 2016, 224), and "younger travellers find reviews more important for deciding where to stay" (Gretzel and Yoo, 2008, 43).

Service providers are also influenced by posted comments and online ratings. A $10 \%$ increase in the average of ratings leads to a more 5\% increase in online bookings (Ye et al., 2011, 634). "The growth and penetration of the Internet expand the effect of referrals from loyal customers" (Berezina et al., 2015, 4).

Negative ratings should also play a role in increasing service quality and even increasing consumer satisfaction, depending on the feedback from recipients of these reviews. 
ToSEE - Tourism in Southern and Eastern Europe, Vol. 5, pp. 73-88, 2019

O. Ban, L. Droj: COMPARATIVE ANALYSIS OF THE ACCOMMODATION ONLINE OFFER FOR ...

The way the unit chooses to respond to the complaints can satisfy the dissatisfied customers and even can increase loyalty after a service failure. (Cranage and Mattila, $2005,175)$ On the other hand, negative reviews have a lot of attention from readers and tend to be more important than positive ones in unit ratings.

The best way to collect information about consumer satisfaction is that of major booking platforms such as Booking.com, TripAdvisor.com, Expedia.com, Yelp.com and many other international and national platforms. Here information is collected according to a given pattern, ratings, hierarchies, ratings, and thousands of reviews are hosted.

Online tourists' posts have been analyzed in several ways:

- $\quad$ linking online comments with sales (Chevalier and Mayzlin, 2006; Ye et al., 2011);

- $\quad$ linking the rating to online bookings (Ye et al., 2011);

- consumer reaction to the online response given by the providers to critical reviews (Min, Lim and Magnini, 2014);

- the link between positive / negative comments and occupancy / RevPar (Phillips et al., 2016);

- the identification of the quality of accommodation characteristics that correlates most strongly with economic indicators (Phillips et al., 2016);

- the content of the comments (Willemsen et al., 2011; Ban et al., 2015) and its use as sources of value creation in the hotel environment (Molnar and Moraru, 2017);

- $\quad$ visitors' response to posted comments (Wu et al., 2016);

- the impact of positive comments (Phillips et al., 2016; Duan, Gu and Whinston, 2008);

- $\quad$ persuasive tactics used on online platforms (Otterbacher, 2011);

- the nature of opinions and possible causes, systematically positive for erroneous reasons (Akay, 2014; Resnik and Zeckhauser, 2002; Wu et al., 2016);

- researching consumer motivations to post reviews (Bronner and de Hoog, in Filieri and McLeay, 2014, 45);

- the rating and complaints about hotel services are reviewed (Del Chiappa and Dall Aglio, 2012);

- $\quad$ the credibility of online reviews (Yoo and Gretzel, 2009; Dickinger, 2011).

The Romanian reservation accommodation market is dominated by Booking.com, which also covers over $50 \%$ of the sales of some accommodation units. Feedback on the benefits of Booking is shared and both consumers and service providers recognize their usefulness. Despite high commissions, hoteliers feel compelled to collaborate with Boooking.com due to popularity among customers, the source quoted above quotes. However, not all units are allowed to work with Booking.com.

On Booking.com it is allowed to make an assessment and record a review only by the actual customers of the listed units, proven quality by making the reservation and confirming it on Booking.com. There are 7 features after which they are rated on a scale of 1 to 10 accommodation units. The average of the seven characteristics is considered to be the performance associated with the evaluated units. 
ToSEE - Tourism in Southern and Eastern Europe, Vol. 5, pp. 73-88, 2019

O. Ban, L. Droj: COMPARATIVE ANALYSIS OF THE ACCOMMODATION ONLINE OFFER FOR ...

The evaluation features used by Booking.com are: location, staff, cleanliness, comfort, value for money, facilities and free $\mathrm{Wi}-\mathrm{Fi}$.

The rating of the units is based on the average of the rating of the characteristics, without importance evaluating of characteristics and without a dimension that shows the overall satisfaction, with the disadvantages that arise from this situation (Ban and Bădulescu, 2015, 63).

On the other hand, the valuation values are very high, which does not really reflect the evaluators' satisfaction and often contrasts with the nature of the comments. The ratings on major review platforms tend to be overwhelmingly positive, occasionally mixed with a small number of deeply negative reviews, giving rise to what has been characterized by (Hu et al., 2009, 145) as "J-shaped distribution". For this reason, an analysis of the comments is required, beyond the ratings posted. In addition, Spark and Browning (2011) also indicate that consumers are more likely to weigh negative reviews ( in Yi et al., 2016, 3).

\section{ACCOMMODATION OFFER FOR BAILE FELIX AND HAJDÚSZOBOSZLÓ RESORTS}

Hajdúszoboszló is a spa town, the largest thermal resort in Europe, located in the Great Plain of Hungary and approx. $75 \mathrm{~km}$ from Băile Felix. The main attraction is the spa complex with 30 ha thermal water pools, Aquapark and Aqua-Palace. "The spa complex offers unforgettable adventures throughout the year for guests, families with small and large children for recovery and recreation" (Hajdúszoboszló Turisztikai Nonprofit Kft, 2010). The water in the thermal baths contains mostly sodium chloride and ammonium chloride, bromine, iodine, as well as carbonates, nitrates and other chemical elements such as lithium, iron and magnesium. In the spa complex in Hajdúszoboszló, besides bathing trunks, guests can also choose about 40 types of treatments, which show their benefits especially by combining them. The most famous treatments are: bathing suits, mud treatments, weight bath, underwater massage with water jet (Hajdúszoboszlói Turisztikai Nonprofit Kft, 2010).

Accommodation is made in boarding houses, hotels, apartments (about 1,500 places) and camping, where there are 5000 available places. In total there are about 15,000 accommodation places.

Băile Felix resort is located in the northwestern part of Romania, in Bihor county, about $9 \mathrm{~km}$ from Oradea and $22 \mathrm{~km}$ from the border crossing point Borş. Băile Felix resort supplys conditions for relaxation, vacation, rest and recovery. Along with the gentle climate, the resort's very valuable natural resources are the thermal waters. The temperature of the thermal waters is between 20-49 degrees Celsius. In Băile Felix are many pools part of big hotels or like The Apollo - Felix which is a open air public bath or a aquatic park named President Aquapark. The thermal waters in the resort are used to treat diseases such as: inflammatory rheumatic diseases (rheumatoid polyarthritis, ankylosing spondylosis); degenerative rheumatic diseases (cervical, dorsal and lumbar spondylosis, polyarthrosis); abarticular rheumatic disorders; post-traumatic conditions; 
ToSEE - Tourism in Southern and Eastern Europe, Vol. 5, pp. 73-88, 2019

O. Ban, L. Droj: COMPARATIVE ANALYSIS OF THE ACCOMMODATION ONLINE OFFER FOR ...

peripheral neurological disorders; central neurological disorders; gynecological disorders; associated diseases (nutrition and metabolism diseases, endocrine diseases). The resort has numerous accommodation structures: 16 hotels (of which 1 are 5 stars), boarding houses, villas (4), etc. with a total of over 7,000 accommodation places, some sources says about 11.000 accommodation places.

\section{METHODOLOGY AND RESULTS}

The purpose of the study is the comparative analysis of Baile Felix resort and Hajdúszoboszló resort. We assume that the evaluation of the two resorts is largely carried out by customers looking for the same types of services, being direct competitors.

The objectives of the study are:

- identifying the objective differences resulting from the quantitative and qualitative analysis of the accommodation offer of the two resorts, as evidenced by the information provided by Booking.com;

- identifying the quantitative and structural differences of accommodation reviewers;

- the comparative analysis of ratings obtained on the seven quality assessment characteristics and types of accommodation structure;

- determining the weight of negative comments in total comments and the issues mentioned in negative reviews by their frequency.

The data used in this empirical study was obtained from a popular third party website, Booking.com, which is the most used third party website for reservation in Romania and one of the largest travel community in Europe.

The research was based on taking over the data listed on the Booking.com platform, with the topic "accommodation in Baile Felix" and "accommodation in Hajduszoboszlo".

With statistics available on Booking.com, the units listed on 29 September 2018 were taken into account. 69 properties in Baile Felix resulted, while 447 properties were displayed in Hajdúszoboszló. These properties were compared comparatively after some of the criteria proposed by Booking.com. This analysis is restricted by the fact that not all the accommodation offer of the two resorts is listed on Booking.com and that different offers are shown differently both in quantity and in structural terms, so it may not have been taken into account either at least all existing units on Booking.com on the date of your search. Beyond these restrictions, the analyzed situation is that of Tables 1 . The comparison was made in terms of relative values. It should be noted that the unit rating is compared regardless of the number of seats held, whether it is a hotel or an apartment. 
ToSEE - Tourism in Southern and Eastern Europe, Vol. 5, pp. 73-88, 2019

O. Ban, L. Droj: COMPARATIVE ANALYSIS OF THE ACCOMMODATION ONLINE OFFER FOR ...

Tables 1: Data for analysis

\begin{tabular}{|c|c|c|c|c|}
\hline \multirow{3}{*}{$\begin{array}{l}\text { Total units } \\
\text { Star Rating }\end{array}$} & \multirow{2}{*}{\multicolumn{2}{|c|}{ Băile Felix }} & \multicolumn{2}{|c|}{ Hajdúszoboszló } \\
\hline & & & \multicolumn{2}{|c|}{447} \\
\hline & $\begin{array}{c}\text { Absolute } \\
\text { values }\end{array}$ & $\begin{array}{c}\text { Relative } \\
\text { values }\end{array}$ & $\begin{array}{c}\text { Absolute } \\
\text { values }\end{array}$ & $\begin{array}{c}\text { Relative } \\
\text { values }\end{array}$ \\
\hline 5 stars & 1 & $1.44 \%$ & 1 & $0.22 \%$ \\
\hline 4 stars & 4 & $5.79 \%$ & 14 & $3.13 \%$ \\
\hline 3 stars & 32 & $46.37 \%$ & 16 & $3.57 \%$ \\
\hline 2 stars & 9 & $13.04 \%$ & 0 & $0 \%$ \\
\hline unrated & 23 & $33.33 \%$ & 416 & $93.06 \%$ \\
\hline Total & 69 & $100 \%$ & 447 & $100 \%$ \\
\hline \multicolumn{5}{|l|}{ Property type } \\
\hline Hotels & 14 & $20.28 \%$ & 33 & $7.38 \%$ \\
\hline Pensions/Guest houses & 39 & $56.52 \%$ & 52 & $11.63 \%$ \\
\hline Apartaments & 10 & $14.49 \%$ & 317 & $70.91 \%$ \\
\hline Homestays & 4 & $5.79 \%$ & 25 & $5.59 \%$ \\
\hline Other & 2 & $2.89 \%$ & 20 & $4.47 \%$ \\
\hline \multicolumn{5}{|l|}{ Popular filters } \\
\hline Parking & 68 & $98.55 \%$ & 445 & $99.55 \%$ \\
\hline Pets allowed & 15 & $21.73 \%$ & 167 & $37.36 \%$ \\
\hline Free WiFi & 67 & $97.1 \%$ & 422 & $94.4 \%$ \\
\hline Spa and wellness centre & 15 & $21.73 \%$ & 19 & $4.25 \%$ \\
\hline \multicolumn{5}{|l|}{ Room facilities } \\
\hline Private bathroom & 68 & $98.55 \%$ & 387 & $86.57 \%$ \\
\hline Air conditioning & 45 & $65.21 \%$ & 279 & $62.41 \%$ \\
\hline Flat-screen TV & 49 & $71.01 \%$ & 259 & $57.94 \%$ \\
\hline Kitchen/Kitchenette & 26 & $37.68 \%$ & 389 & $87.02 \%$ \\
\hline \multicolumn{5}{|l|}{ Review score } \\
\hline Rating 9+ & 31 & $44.92 \%$ & 170 & $38.03 \%$ \\
\hline Rating 8-9 & 27 & $39.13 \%$ & 145 & $32.43 \%$ \\
\hline Rating 7-8 & 7 & $10.14 \%$ & 39 & $8.72 \%$ \\
\hline Rating 6-7 & 1 & $1.44 \%$ & 5 & $1.11 \%$ \\
\hline No rating & 3 & $4.34 \%$ & 88 & $19.68 \%$ \\
\hline
\end{tabular}

Source: processed after Booking.com, accessed on 29 September 2018

A sample consisting of $20-30 \%$ of the listed units was formed, respecting the weight by type of structure. Thus, 20 units were selected from Baile Felix and 100 units from Hajdúszoboszló. (Tables 2) For each type of structure on the two resorts, selection of the sample was made by selecting the units by adding the resulting sample fraction (total population / sample). Only units with more than 10 ratings have been selected. 
ToSEE - Tourism in Southern and Eastern Europe, Vol. 5, pp. 73-88, 2019

O. Ban, L. Droj: COMPARATIVE ANALYSIS OF THE ACCOMMODATION ONLINE OFFER FOR ...

Tables 2: Units selected in the sample

\begin{tabular}{|c|c|c|c|}
\hline \multicolumn{2}{|c|}{$\begin{array}{l}\text { Băile Felix-total units listed on } \\
\text { Booking.com }\end{array}$} & \multicolumn{2}{|c|}{$\begin{array}{l}\text { Băile Felix-total units selected in sample } \\
(30 \%)\end{array}$} \\
\hline Total 69 units, from which: & $100.00 \%$ & Total 20 units, from which: & $30 \%$ \\
\hline 38 pensions/guest houses & $55 \%$ & 11 pensions/guest houses & $55 \%$ \\
\hline 14 hotels & $20.28 \%$ & 4 hotels & $20.28 \%$ \\
\hline 8 apartaments & $11.59 \%$ & 2 apartaments & $11.59 \%$ \\
\hline 9 other & $13.04 \%$ & 3 other & $13.04 \%$ \\
\hline \multicolumn{2}{|c|}{$\begin{array}{l}\text { Hajdúszoboszló-total unități listate pe } \\
\text { Booking.com }\end{array}$} & \multicolumn{2}{|c|}{$\begin{array}{l}\text { Hajdúszoboszló-total unități selectate în } \\
\text { eșantion }(22 \%)\end{array}$} \\
\hline Total 447 units, from which: & $100.00 \%$ & Total 100 units, from which: & $22 \%$ \\
\hline 53 pensions/guest houses & $11.85 \%$ & 16 pensions/guest houses & $11.85 \%$ \\
\hline 34 hotels & $7.6 \%$ & 10 hotels & $7.6 \%$ \\
\hline 323 apartaments & $72.25 \%$ & 65 apartaments & $72.25 \%$ \\
\hline 25 homestays/villas & $5.59 \%$ & 7 homestays/villas & $5.59 \%$ \\
\hline 7 other & $1.56 \%$ & 2 other & $1.56 \%$ \\
\hline
\end{tabular}

Source: Processing by Booking.com, accessed on 29 September 2018

Note: The situation in the table is the units listed on the date of access

For the selected units, a series of data contained in an excel file, separated for each destination, was extracted (Tables 3).

Tables 3: Research items selected

\begin{tabular}{|c|} 
Unit name \\
Type of unit \\
Classification \\
Rating medium \\
Rating on each characteristics from the seven proposed by Booking.com (Staff, Location, \\
Cleanliness, Value for money, Comfort, Facilities, Free WiFi ) \\
Number of reviewers \\
Structure of reviewers (families, couples,groups of friends, solo travellers, business travelers) \\
Nationality of reviewrs (Romanian, Magyar, Other) \\
Number of evaluations \\
Number of reviews with comments \\
Number of positive evaluations \\
Number of negative evaluations* \\
Total frequency of negative aspects mentioned in reviews for each destination
\end{tabular}

Source: Processing by Booking.com, accessed on 29 September 2018

* The negative character of the rating after the title given to the comment has been determined

For comment analysis, content analysis was used, which is a technique often used in text analysis by code schemes (Weber, 1985). Text review was performed to evaluate posted comments. The code scheme, after which the analysis was made, was determined after the analysis of 50 comments on each resort. They are described below (Tables 4$)$. The process was difficult because the comments were in different languages: Romanian, English, Hungarian, Russian, Polish, Czech, French, Italian, Swedish, Norwegian, etc. In the automatic translation the meaning of the expression was lost, which is why the manual translation was done. The negative or positive character of the message has been determined by the comment title posted. The title was considered as a synthesis of 
ToSEE - Tourism in Southern and Eastern Europe, Vol. 5, pp. 73-88, 2019

O. Ban, L. Droj: COMPARATIVE ANALYSIS OF THE ACCOMMODATION ONLINE OFFER FOR ...

impressions and as a reflection of the degree of satisfaction, reflection more faithful than the average of the evaluation of that the seven characteristics. Unfortunately, Booking.com does not record global satisfaction, but only makes the average of the seven characteristics, which is a minus sign of quality perception, as has been shown in other studies (Ban and Bădulescu, 2015, 63).

\section{Tables 4: Description of categories analised}

\begin{tabular}{|c|c|}
\hline Category & Description \\
\hline Food & $\begin{array}{l}\text { In terms of food, negative observations were made about: too little, } \\
\text { the quality of the preparation, the quality of the ingredients, the } \\
\text { reduced diversity, the non-compliance with the different diets. }\end{array}$ \\
\hline Staff & $\begin{array}{l}\text { As regards the staff, the two destinations were observed, different } \\
\text { observations: in Baile Felix the staff behavior was criticized, while } \\
\text { in Hajdúszoboszló the criticism was that the staff speaks no } \\
\text { language other than Hungarian or discriminates against the } \\
\text { Romanian clients. }\end{array}$ \\
\hline Cleanliness & $\begin{array}{l}\text { In terms of cleaning it is mentioned at the level of: room, bathroom, } \\
\text { wellness area and dining place. }\end{array}$ \\
\hline Bed & $\begin{array}{l}\text { Observations regarding the bed concern: the small size, the quality } \\
\text { of the mattress, the smell of the linen }\end{array}$ \\
\hline Size of room/ bathroom & $\begin{array}{l}\text { Reflective observations on the size of the rooms refer to: rooms, } \\
\text { bathrooms, terraces / balconies. }\end{array}$ \\
\hline Old furniture & $\begin{array}{l}\text { Obsolete furniture is brought into discussion by: cabinets, beds, } \\
\text { carpet, hanger. }\end{array}$ \\
\hline Installations & $\begin{array}{l}\text { Regarding the installations, observations were made regarding: } \\
\text { their malfunction or poor functioning (air conditioner, TV with few } \\
\text { channels and only in Hungarian, refrigerator, etc.). }\end{array}$ \\
\hline Other tourists & $\begin{array}{l}\text { Criticism about other tourists refers to: the lamentations they make, } \\
\text { the lack of cleanliness in the wellness area, the unsupervised } \\
\text { children. }\end{array}$ \\
\hline Wellness area & $\begin{array}{l}\text { Observations regarding the wellness area refer to: too small spaces, } \\
\text { too cold water, short program of operation, non-functional pools, } \\
\text { unavailable services. }\end{array}$ \\
\hline Elevator & $\begin{array}{l}\text { Regarding the lift, the observations are either: they work hard, they } \\
\text { are too few for necessity, they make a laugh. }\end{array}$ \\
\hline $\begin{array}{l}\text { Other } \\
\text { parking,payment,insects, } \\
\text { differences from } \\
\text { Booking.com }\end{array}$ & $\begin{array}{l}\text { Other remarks have been made about: parking (inadequate places, } \\
\text { as it is costly, not illuminated at night); insects (there are no } \\
\text { mosquito nets), differences to Booking.com (some conditions have } \\
\text { been reserved and some have been received, one has been given a } \\
\text { price and another is asked for higher) that you can not pay with the } \\
\text { card, that they are not given bills, that it takes a lot of check-out. }\end{array}$ \\
\hline
\end{tabular}

Source: created by authors 
ToSEE - Tourism in Southern and Eastern Europe, Vol. 5, pp. 73-88, 2019

O. Ban, L. Droj: COMPARATIVE ANALYSIS OF THE ACCOMMODATION ONLINE OFFER FOR ...

\section{HYPOTHESIS AND RESEARCH RESULTS}

The hypothesis is based on the premise that the Hajdúszoboszló resort is more performing than Baile Felix, in terms of the quality of the offer, the premise supported by the opinion of the Romanian tourism consumers in western Romania.

The following hypotheses were based on the basis of the research:

H1 The resort of Baile Felix compared to Hajdúszoboszló is inferior in quality from the point of view of the classification of accommodation units.

H2 The resort of Baile Felix compared to Hajdúszoboszló is inferior in terms of quality perceived by current customers.

H3 There are fewer foreign tourists in Baile Felix than in Hajdúszoboszló.

H4 The customer structure for the two resorts is different.

H5 The analysis of customer comments reveals for the two resorts a greater share of negative comments in the case of Baile Felix resort than Hajdúszoboszló.

H6 The analysis of customer reviews on the seven features proposed by Booking.com reveals different quality problems for the two resorts.

To verify the $\mathrm{H} 1$ hypothesis, the statistics available on Booking.com on 29 September 2018 were used, where 69 properties were listed in Baile Felix while in Hajdúszoboszló 447 properties were displayed. For this purpose, the data in Tables 1 were analyzed and the differences and magnitude of these differences were assessed. The most significant differences are observed in the structure of the accommodation units types (Figure 1) and their star rating.

In the Băile Felix resort, classical accommodation structures (hotels and hostels) and star rating are predominant, while in Hajdúszoboszló the apartments predominate as a form of accommodation without classification (Figure 1). In the Băile Felix resort there are predominant units classified as stars $(66.67 \%)$, while in the Hajdúszoboszló resort the unclassified units (93.06\%) predominate. Comparison in terms of classification is not relevant in this case. However, we can see that the share of 4 and 5 star units is near (Tables 1). H1 hypothesis is not confirmed.

In terms of quality perception, overall data on the review score (Tables 1).

Taking into account the perceived quality reflected in the Booking.com score, there are no significant differences between the two resorts, but quite a symmetrical arrangement. The only exception is units that are not yet reviewed or that do not have enough reviews to be included in the hierarchy, which has a $19.68 \%$ share in Hajdúszoboszló compared to $4.34 \%$ in Băile Felix. 
ToSEE - Tourism in Southern and Eastern Europe, Vol. 5, pp. 73-88, 2019

O. Ban, L. Droj: COMPARATIVE ANALYSIS OF THE ACCOMMODATION ONLINE OFFER FOR ...

Figure 1: Comparison between Băile Felix and Hajdúszoboszló, as accommodation types

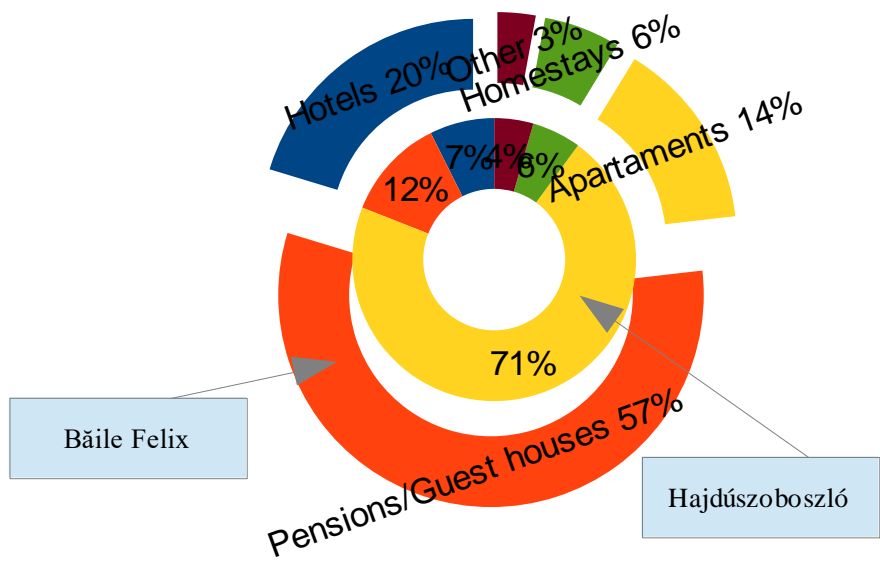

Source: processed from Booking.com and created by authors

By eliminating the units not included in the hierarchy, a more accurate comparison can be made showing how similar the results for the two stations are (Figure 2).

H3 There are fewer foreign tourists in Baile Felix than in Hajdúszoboszló.

Given that this information can only be collected by analyzing the country of origin of those who post comments for each unit, this information was gathered for the sample set out in Table 2. For each resort, reviewers were divided by origin in: Romanians, Hungarians and other foreigners. In the Baile Felix resort, the structure of the nationalities of the visitors who made a rating on Booking.com is as follows: 3707 (91.87\%) Romanians, 75 Hungarians (1.85\%) and 253 (6.27\%) foreigners, other than Hungarians. Nationality was established after the residence declared on Booking.com. Total foreigners (Hungarians and other nationalities) are $8.12 \%$ (328) of the total number of visitors.

In Hajdúszoboszló the nationality structure of the visitors who made a rating on Booking.com is as follows: 3128 (26.34\%) Romanians, 3989 (33.59\%) Hungarians and $4756(40.04 \%)$ foreigners, other than Hungarians. Foreigners (Romanians and other nationalities) are $66.39 \%$ (7884) of the total number of visitors.

H3 hypothesis confirmed, there are more foreign tourists in Hajdúszoboszló than in Băile Felix

H4 The customer structure for the two resorts is different. 
ToSEE - Tourism in Southern and Eastern Europe, Vol. 5, pp. 73-88, 2019

O. Ban, L. Droj: COMPARATIVE ANALYSIS OF THE ACCOMMODATION ONLINE OFFER FOR ...

On Booking.com, the customer structure is analyzed by travel mode: family, couple, group of friends, as well as single travelers and in the interest of the service. The analysis of the situation on the two resorts shows important similarities. The order of organizational types of tourists is the same: couples, families, groups of friends, single travelers and business travelers. The difference lies in slightly different weights, respectively in Hajdúszoboszló between the first two categories is a bigger difference ( $4.17 \%$ compared to $0.61 \%$ in Baile Felix) and respectively in categories 3 and $4(7.03 \%$ versus $3.1 \%$ in Baile Felix) .

Figure 2: Ratings for units rated

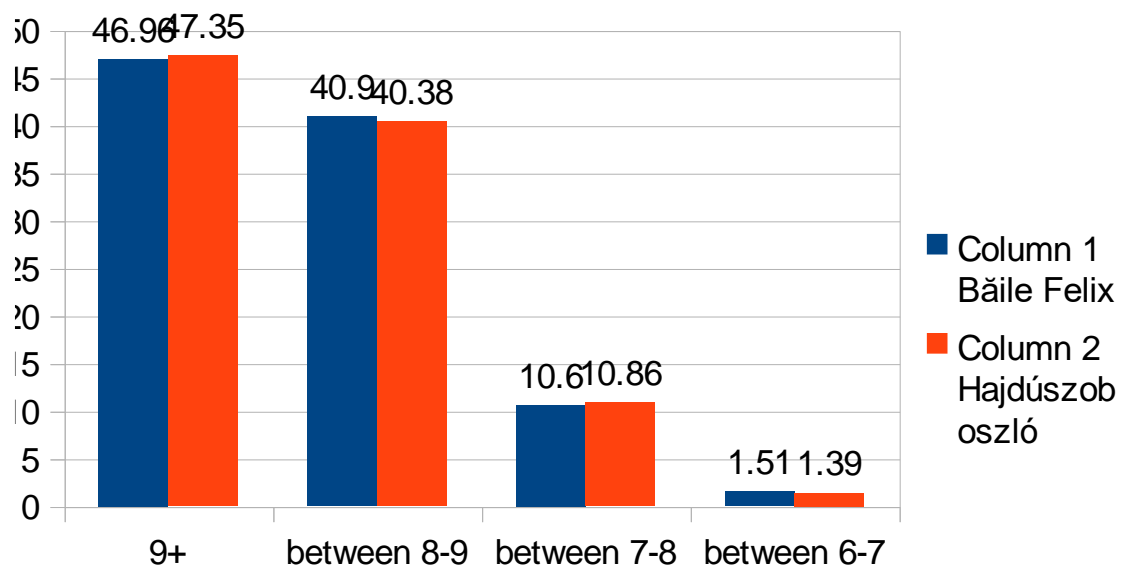

Source: processed from Booking.com and created by authors

Because the structure of the two resorts is respected as a type of organization of tourists, as an order of organizational types according to the total weight, we will consider that $\mathrm{H} 4$ is not confirmed.

H5 The analysis of customer comments reveals for the two resorts a greater share of negative comments in the case of Baile Felix resort than Hajdúszoboszló.

From the total of 4404 reviews for Băile Felix, 2965 are accompanied by text comments. Depending on the title given to the comment, we have determined the positive or negative nature of the comment. 299 negative comments were identified, ie $10.08 \%$.

Of the 11879 reviews for Hajdúszoboszló, 6413 are accompanied by text comments. Depending on the title given to the comment, we have determined the positive or negative nature of the comment. 496 negative comments were identified, ie $7.73 \%$. 
ToSEE - Tourism in Southern and Eastern Europe, Vol. 5, pp. 73-88, 2019

O. Ban, L. Droj: COMPARATIVE ANALYSIS OF THE ACCOMMODATION ONLINE OFFER FOR ...

We find for the two nearest weights the negative comments in the total comments, with a slightly higher weight for Baile Felix. The hypothesis is confirmed, with the reserve that the difference is $2.35 \%$.

H6 Analysis of customer reviews on the seven features proposed by Booking.com and posted comments reveals different quality problems for the two resorts.

This analysis of perceived quality was done in two dimensions: from the point of view of the seven quality characteristics proposed by Booking.com and by analyzing the text of the negative comments posted by the clients. Both researches were realised on the units contained in the two samples, 20 units in Baile Felix and 100 units in Hajdúszoboszló.

The comparative analysis on characteristics revealed minor differences, below $0.3 \%$, on the two resorts (Tables 6). As a result, this part of the hypothesis is not confirmed.

However, the deeper analysis of the negative comments posted (Table 7) revealed the most important quality problem for Baile Felix, namely Food, which has a $10.5 \%$ share in the total negative comments made, compared to $1.45 \%$ in Hajdúszoboszló. The problem of eating in tourist areas in Romania is old and still unresolved. Food is not diversified and is of poor quality, many times. In addition, in Romanian accommodation units there is not yet established a menu for diet or for regim.

The Staff is a more serious problem in Hajdúszoboszló than in Baile Felix, the main accusation being that the tourism staff speaks no language other than Hungarian. The second staff issue, present in both resorts, is that of bad interaction, lack of courtesy and availability.

Problems related to the specificity of the resort are related to: room / bathroom size, etc. (too little in Hajdúszoboszló) and problems related to the operation of the elevator, specific for Baile Felix where many accommodation structures are arranged vertically. The problem of the functioning of the installations, present in both resorts, but with a higher weight in Baile Felix refers especially to the room temperature.

Tables 5: Clients ratings on Booking.com

\begin{tabular}{|l|c|c|c|c|c|c|c|}
\hline \multicolumn{1}{|c|}{ Rating } & Cleanliness & Comfort & Facilities & Staff & $\begin{array}{c}\text { Value for } \\
\text { money }\end{array}$ & $\begin{array}{c}\text { Free } \\
\text { WiFi }\end{array}$ & Location \\
\hline Băile Felix & 9.1 & 8.8 & 8.7 & 9 & 8.6 & 7.8 & 8.8 \\
\hline Hajdúszoboszló & 9 & 8.6 & 8.7 & 9.1 & 8.7 & 7.6 & 9.1 \\
\hline
\end{tabular}

Source: processed from Booking.com and created by authors 
ToSEE - Tourism in Southern and Eastern Europe, Vol. 5, pp. 73-88, 2019 O. Ban, L. Droj: COMPARATIVE ANALYSIS OF THE ACCOMMODATION ONLINE OFFER FOR ...

Tables 6: Frequency of problemes mentioned by clients in comments

\begin{tabular}{|l|c|c|}
\hline Type of problem & $\begin{array}{l}\text { Băile Felix } \\
\text { (\% in total } \\
\text { reviews) }\end{array}$ & $\begin{array}{l}\text { Hajdúszoboszló } \\
\text { (\% in total reviews) }\end{array}$ \\
\hline Food & 10.5 & 1.45 \\
\hline Staff & 4.02 & 6.3 \\
\hline Cleanliness & 4.73 & 4.5 \\
\hline Bed & 2.28 & 1.56 \\
\hline Size of room/bathroom & - & 1.09 \\
\hline Old furniture & 1 & 0.58 \\
\hline Installations & 5.74 & 2.0 \\
\hline Other tourists & 0.59 & 0.58 \\
\hline Wellness area & 0.59 & 0.53 \\
\hline Elevator & 3.04 & 0.58 \\
\hline $\begin{array}{l}\text { Other(parking,payment, insects, differences } \\
\text { from Booking.com etc.) }\end{array}$ & $<0.53$ & $<0.53$ \\
\hline
\end{tabular}

Source: processed from Booking.com and created by authors

Regarding posted posts, an interesting aspect is that of the relationship between the average of the rating and the title given to the comment, which is a declaration of satisfaction for the entire stay. It has been noticed that for the same average of assessments, the conclusions may be very different on the same resort or even the same accommodation structure (Tables 7). For example, in Tables 7 it can be seen that for the same average of 6.2 or 5.0 assessments, the conclusions are different from one tourist to another. For some it means Pleasant stay, for others Awful, etc.

These situations call into question the need to register global reservation satisfaction platforms as a separate indicator from the average of the rating on features. Quality features vary significantly from one reviewer to another.

\section{Tables 7: Different conclusions for the same rating}

\begin{tabular}{|l|c|}
\hline $\begin{array}{l}\text { Name of the } \\
\text { accommodation structure }\end{array}$ & Hajdú Vendégház \\
\hline Headline & Pleasent \\
\hline Global Rating & 6.2 \\
\hline Date & Hotel Rudolf \\
\hline $\begin{array}{l}\text { Name of the } \\
\text { accommodation structure }\end{array}$ & $\begin{array}{c}\text { Only for those who have moderate needs and tolerates } \\
\text { discomfort }\end{array}$ \\
\hline $\begin{array}{l}\text { Headline } \\
\text { (Csak azoknak, akiknek visszafogott igényeik vannak, és jól } \\
\text { türik a kellemetlenségeket) }\end{array}$ \\
\hline $\begin{array}{l}\text { Global Rating } \\
\text { Daccommodation structure }\end{array}$ & 6.2 December 2016 \\
\hline Headline & Lotus Therm \\
\hline Global Rating & Disappointing \\
\hline
\end{tabular}


ToSEE - Tourism in Southern and Eastern Europe, Vol. 5, pp. 73-88, 2019 O. Ban, L. Droj: COMPARATIVE ANALYSIS OF THE ACCOMMODATION ONLINE OFFER FOR ...

\begin{tabular}{|l|c|}
\hline Date & 7 February 2018 \\
\hline $\begin{array}{l}\text { Name of the } \\
\text { accommodation structure }\end{array}$ & Plage Hotel \\
\hline Headline & Acceptable \\
\hline Global Rating & Decembre 2017 \\
\hline Date & \\
\hline $\begin{array}{l}\text { Name of the } \\
\text { accommodation structure }\end{array}$ & Plage Hotel \\
\hline Headline & Awful \\
\hline Global Rating & 20 April 2018 \\
\hline Date & \\
\hline
\end{tabular}

Source: extracted from Booking.com and created by authors

\section{CONCLUSION AND FUTURE RESEARCH}

The objectives of the project were achieved by the comparative analysis of the online accommodation offer in the two resorts Baile Felix and Hajdúszoboszló. On the whole, there are many similarities but also subtle differences, which can be the source of the different economic performance of the two resorts. Below are the hypotheses formulated and the results obtained.

H1 The resort of Baile Felix compared to Hajdúszoboszló is inferior in quality from the point of view of the classification of accommodation units. H1 hypothesis is not confirmed.

H2 The resort of Baile Felix compared to Hajdúszoboszló is inferior in terms of quality perceived by current customers. The hypothesis $\mathrm{H} 2$ is not confirmed.

H3 There are fewer foreign tourists in the Baile Felix resort than in Hajdúszoboszló. The H3 hypothesis is confirmed, in Hajdúszoboszló there are many foreign tourists than in Băile Felix.

H4 The customer structure for the two resorts is different. Because the structure of the two resorts is respected as a type of organization of tourists, as an order of organizational types according to the total weight, we will consider that $\mathrm{H} 4$ is not confirmed.

H5 The analysis of customer comments reveals for the two resorts a greater share of negative comments in the case of Baile Felix resort than Hajdúszoboszló. The H5 hypothesis is confirmed, with the exception that the difference is $2.35 \%$.

H6 The analysis of customer reviews on the seven features proposed by Booking.com reveals different quality problems for the two resorts. The comparative analysis on features revealed minor differences below $0.3 \%$ on the two resorts. As a result, this part of the hypothesis is not confirmed. However, the deeper analysis of the negative comments posted revealed the quality of the different accommodation offer as well as the incidence in Hajdúszoboszló towards Băile Felix. In Hajdúszoboszló the most important problem is staff, who do not speaks languages other than Hungarian and has inappropriate behavior towards tourists. For Băile Felix, the most important issue is the 
ToSEE - Tourism in Southern and Eastern Europe, Vol. 5, pp. 73-88, 2019

O. Ban, L. Droj: COMPARATIVE ANALYSIS OF THE ACCOMMODATION ONLINE OFFER FOR ...

undiversified and poor quality food, followed by the rude staff problem. A specific problem for Hajdúszoboszló is that of small accommodation (rooms, bathrooms) and for Felix Baths the lack or the proper functioning of the elevator. H6 hypothesis is partially confirmed.

The empirical contribution is that this work makes an analysis that has not been done in the past for these resorts. This research is valuable because it compares the information on the two resorts on the very popular booking platform, Booking.com. In addition, there are two resorts in direct competition and positioned close to each other. The practical implications of this study are valuable, by the results obtained, for the tourism operators in the two resorts. There are known sources of consumer dissatisfaction and these are analyzed comparatively on the two competing resorts. The implications of the study are of a social nature, considering that the high complaints of tourists are also related to discrimination issues, felt in the accommodation structures. Our study shows a major deficiency of these platforms, which is to record only the evaluation of some characteristics rather than global satisfaction. This deficiency is seen in assessments with equal marks but different conclusions. This conclusion highlights the usefulness of the Importance-Performance Analysis, which takes into account the importance of each evaluator's valued characteristics. The scientific contribution of the study is that it highlights the need to know the importance given by reviewers to the quality characteristics (in accordance with Importance-Performance Analysis), in order to properly assess the satisfaction of the consumers of tourist services. Future research aims at the analysis of the two resorts, by the already established samples, from the perspective of the general economic indicators, as well as the specifics of the accommodation activity. The correlations between the quality level of the unit and its economic performance will also be pursued.

\section{REFERENCES}

Askay, D.A. (2014), "Silence in the crowd: The spiral of silence contributing to the positive bias of opinions in an online review system", New Media \& Society, pp. 1-19.

Ban, O., V. Ancusa, V. Bogdan and Tara, Gh.I. (2015), "Empirical Social Research to Identify Clusters of Characteristics that Underlie the Online Evaluation of Accommodation Services", Revista de Cercetare si Interventie Sociala, 50, pp. 293-308.

Ban, O., and Bădulescu, A. (2015), "The online evaluation of accommodation services quality andthe overall satisfaction", Revista Româna de Marketing, No. 4, pp. 60-70.

Berezina, K., Bilgihan, A., Cobanoglu, C. and Okumus, F. (2015), "Understanding Satisfied and Dissatisfied Hotel Customers: Text Mining of Online Hotel Reviews", Journal of Hospitality Marketing \& Management, 00, pp. 1-24.

Chevalier, J.A. and Mayzlin D. (2006), "The effect of word of mouth on sales: online book reviews", Journal of Marketing Research, Vol. 43, No. 3, pp. 345-354.

Cranage, D.A., and Mattila, A.S. (2005), "Service recovery and pre-emptive strategies for service failure: Both lead to customer satisfaction and loyalty, but for different reasons", Journal of Hospitality \& Leisure Marketing, Vol. 13, No. 3/4, pp. 161-181.

Del Chiappa G. and Dall'Aglio S. (2012), "Factors influencing Travellers' e-Ratings and e-Complaints about Hotel Services: Insights from an Italian Tourism Destination”. In: Fuchs M., Ricci F., Cantoni L. (eds) Information and Communication Technologies in Tourism, Springer, Vienna.

Dickinger, A. (2011), "The Trustworthiness of Online Channels for Experience- and Goal-Directed Search Tasks", Journal of Travel Research, Vol. 50, No. 4, pp. 378-391. https://doi.org/10.1177/0047287510371694

Duan, W., Gu, B. and Whinston, A.B. (2008), "Do Online Reviews Matter? - An Empirical Investigation of Panel Data", Decision Support Systems, Vol. 45, No. 4, pp. 1007-16. 
ToSEE - Tourism in Southern and Eastern Europe, Vol. 5, pp. 73-88, 2019

O. Ban, L. Droj: COMPARATIVE ANALYSIS OF THE ACCOMMODATION ONLINE OFFER FOR ...

Filieri, R., and McLeay, F. (2014), "E-WOM and Accommodation: An Analysis of the Factors That Influence Travelers' Adoption of Information from Online Review", Journal of Travel Research, Vol. 53, No. 1, pp. 44.57 https://doi.org/10.1177/0047287513481274

Gretzel, U., and Yoo, H. K. (2008), "Use and impact of online travel reviews", Information and Communication Technologies in Tourism, 2, pp. 35-46.

Hajdúszoboszlói Turisztikai Nonprofit Kft (2010), Hajdúszoboszló The city of well-being, viewed 19 November 2018, https://hajduszoboszlo.hu/ro/

Hu, N., Zhang, J. and Pavlou, P.A. (2009), "Overcoming the j-shaped distribution of product reviews", Communications of the ACM, Vol. 52, No. 10, pp. 144-147.

Li, H., Ye, Q. and Law, R. (2013), "Determinants of Customer Satisfaction in the Hotel Industry: An Application of Online Review Analysis", Asia Pacific Journal of Tourism Research, Vol. 18, No. 7, pp. 784-802, https://doi.org/10.1080/10941665.2012.708351

Litvin, S., Goldsmith, R. And Pan, B. (2008), "Electronic word-of-mouth in hospitality and tourism management", Tourism Management, 29, pp. 458-468.

Min, H., Lim, Y. and Magnini, P. (2014), "Factors Affecting Customer Satisfaction in Responses to Negative Online Hotel Reviews: The Impact of Empathy, Paraphrasing, and Speed", Cornell Hospitality Quarterly, pp. 1-9.

Molnar E.and Moraru R. (2017), "Content Analysis of Customer Reviews to Identify Sources of Value Creation in the Hotel Environment”. In: Za S., Drăgoicea M., Cavallari M. (eds) Exploring Services Science. IESS 2017. Lecture Notes in Business Information Processing, Vol 279, Springer, Cham.

Otterbacher, J. (2011), "Being heard in review communities: communication tactics and review prominence", Journal of Computer-Mediated Communication, Vol. 16, No. 3, pp. 424-444.

Phillips, P., Barnes, S., Zigan, K. and Schegg, R. (2016), "Understanding the Impact of Online Reviews on Hotel Performance: An Empirical Analysis", Journal of Travel Research, pp. 1-15.

Resnick, P and Zeckhauser, R (2002), "Trust among strangers in Internet transactions: empirical analysis of eBay’s reputation system”, Advances in Applied Microeconomics: A Research Annual, 11, pp. 127 157.

Yi, S; Li, X., and Jai, T.M. (2016), "Hotel guests' perception of best green practices: A content analysis of online reviews", Tourism and Hospitality Research, Vol.18, Issue 2, pp. 191-202. https://doi.org/10.1177/1467358416637251

Ye, Q., Law, R., Gu, B., \& Chen, W. (2011), "The influence of user-generated content on traveler behavior: An empirical investigation on the effects of e-wordof- mouth to hotel online bookings", Computers in Human Behavior, Vol. 27, No. 2, pp. 634-639.

Yoo, K. and Gretzel, U. (2009), "Comparison of deceptive and truthful travel reviews". In W. Hopken, U. Gretzel \& R. Law (Eds.), Information and Communication Technologies in Tourism 2009: Proceedings of the International Conference Vienna, Austria, Springer Verlag, pp. 37-47.

Willemsen LM, Neijens PC, Bronner F. and Ridder, J.A. (2011), "Highly recommended! the content characteristics and perceived usefulness of online consumer reviews", Journal of Computer-Mediated Communication, Vol. 17, No. 1, pp. 19-38

Wu, L., Mattila, A.S., Wang, C.Y. and Hanks, L. (2016), "The Impact of Power on Service Customers' Willingness to Post Online Reviews", Journal of Service Research, Vol. 19, No. 2, 224-238.

Olimpia Ban, PhD, University Professor

University of Oradea, Faculty of Economic Sciences

Department of Economy and Business

1-2 University Street, 410087 Oradea, Romania

Phone: +40 259432830

E-mail: Olimpiaban2008@gmail.com

Laurențiu Droj, PhD, Associate Professor

University of Oradea, Faculty of Economic Sciences

Department of Finance-Accountancy

1-2 University Street, 410087 Oradea, Romania

Phone: +40 259432830

E-mail: laurentiu.droj@gmail.com 